\title{
OBSERVAÇÕES SOBRE O DESENVOLVIMENTO DA OBRA DE MAX HORKHEIMER ${ }^{1}$
}

Jürgen Habermas

No círculo dos teóricos de Frankfurt que se reuniram em estreita cooperação intelectual durante os anos 1930, em Nova York, Horkheimer ocupa um lugar especial. Como diretor do Instituto [Institut für Sozialforschung] e como editor da Revista [Zeitschrift für Sozialforschung], ele não só mantinha em suas mãos, a despeito de Pollock, todos os fios da organização, como também foi incontestavelmente reconhecido como o spiritus rector do conjunto dos programas de pesquisa. A outra face desta posição central foi raramente notada: a própria obra filosófica de Horkheimer desvinculou-se pouco, ou bem menos que a de seus colaboradores, das realizações coletivas do grupo de intelectuais emigrados reunidos a seu redor. Horkheimer permaneceu preso, bem mais fortemente que os demais colaboradores, ao coletivo singular disso que mais tarde chamou-se "Escola de Frankfurt". Não evoco aqui tais circunstâncias porque me interessam questões relativas ao reconhecimento dos méritos individuais, mas sim por razões objetivas e biográficas.

Entre 1932 e 1941, Horkheimer investiu integralmente tanto seu impulso teórico como sua energia intelectual na realização interdisciplinar daquele programa de pesquisa materialista que recebeu seus contornos com Autoridade e Família e com a Revista de

1 Título original do artigo: "Bemerkungen zur Entwicklungsgeschichte des Horkheimerschen Werkes", publicado na coletânea organizada por SCHMIDT, A. \& ALTWICKER, N. Max Horkheimer Heute: Werk und Wirkung, Fischer Verlag, Frankfurt do Meno, 1986, pp. 163-179. Tradução de Maurício Chiarello. Autorização para publicação da tradução concedida pelo próprio autor, Jürgen Habermas, sob licença da editora detentora do copyright (c) 1986 Fischer Taschenbuch Verlag GmbH, Frankfurt am Main. 
Pesquisa Social, delineado inclusive nas resenhas. O fato de que a filosofia, para Horkheimer, devia consumar-se neste trabalho conjunto com economistas, psicólogos, juristas, historiadores e sociólogos, notadamente sociólogos da música e da literatura, tinha sua razão de ser numa convicção filosófica que os demais colaboradores do Instituto não compartilhavam, ou que, em todo caso, não se punha como o primum movens de seus trabalhos. Certamente, todos partiam da necessidade de liberar a teoria marxista da sociedade das cadeias ortodoxas da II e da III Internacionais e, entrementes, relacionar com ela, de um modo franco e imparcial, a sociologia burguesa estabelecida. Todos os colaboradores do Instituto também concordavam que a perspectiva bem sucedida de uma sociedade emancipada, fundada de modo histórico-filosófico, promoveria uma inter-relação entre as disciplinas e concederia uma nova orientação ao trabalho das ciências particulares. Mas unicamente Horkheimer vinculava o programa deste materialismo interdisciplinar a uma idéia diferente da filosofia, e, na verdade, extremamente original: ele desejava continuar a filosofia com outros meios, notadamente com as ciências sociais. Os cientistas sociais não estavam particularmente interessados nisto, e os filósofos do Círculo, Adorno e Marcuse, acharam por bem não tomar a coisa a sério. O conceito de "materialismo" teve sempre para Horkheimer uma conotação de crítica da filosofia; ele se punha como um pensamento pósmetafísico. Juntamente com Marx, Horkheimer acreditava que, com a filosofia de Hegel, as figuras do pensamento filosófico tinham definitivamente chegado ao fim - que todo idealismo, que procurava manter-se fiel à tradição formal em continuação da filosofia hegeliana, entorpecia-se como ideologia e só servia para ocultar a miséria concreta e o sofrimento individual sob conceitos gerais transfiguradores. Juntamente com Marx, Horkheimer entendia que somente se tornando prática a filosofia poderia salvar aquele seu teor de verdade. Mas Horkheimer, aliás cético como Marx, encontrava-se numa situação em que procedia a esperança histórica numa revolução iminente. Destarte, ganhava um peso específico o passo mediador de reconstrução e aperfeiçoamento

Educ. e Filos., Uberlândia, v. 21, n. 42, p. 273-293, jul./dez. 2007. 
das teorias científicas, imunes à ilusão idealista. Sim, esta teoria social revestiu-se de uma nova significação na perspectiva de preservação do teor essencial de uma filosofia esgotada. Horkheimer trata da superação [Aufhebung] da filosofia por meio da teoria social; a transformação científico-social fornece a única chance de sobrevivência para o pensamento filosófico. Hauke Brunkhorst ocupou-se particularmente desta "desconstrução materialista da filosofia". Ele mostrou que Horkheimer, na fase mais produtiva de sua vida, diferentemente de Adorno e Marcuse, foi um antifilósofo ${ }^{2}$.

O fato de o trabalho filosófico de Horkheimer ter sido absorvido pelo trabalho coletivo de seu Círculo deveu-se não à decisão circunstancial de acatar e acentuar o papel da organização científica, mas sim a uma resposta original ao "fim da metafísica" de Heidegger. Enquanto não puder se realizar, a filosofia tem que transigir com outros meios para não se tornar ideologia - e, para Horkheimer, este meio deveria ser uma sociologia [Sozialwissenschaft], ao mesmo tempo em que renovada, associada e fundida com a teoria crítica da sociedade. Em conformidade com esta idéia, a produção de Horkheimer esteve vinculada ao papel de diretor do Instituto e de editor da Revista. A partir dessa conjuntura objetiva, também se esclarecem as conseqüências (tanto biográficas como relativas à história da obra) que o fim dessa cooperação acarretou para o próprio trabalho de Horkheimer. Delas me ocuparei a seguir. Não fazemos injustiça a Horkheimer se afirmamos que sua produtividade científica dos anos 30 concentrou-se em suas grandes contribuições à Zeitschrift für Sozialforschung. Nos trabalhos seguintes, realizados em colaboração com Adorno entre 1941 e 1944, terminou por se completar a viragem para uma filosofia negativista da história. Mas esta

2 Hauke Brunkhorst, "Dialektischer Positivismus des Glücks", in Zeitschrift für philosophische Forschung, vol. 39, caderno 3, 1985, p. 353 e seguintes; cf. também Michael Korthals, "Die kritische Gesellschaftstheorie des frühen Horkheimer. Mißvertändnis über das Verhaltnis von Horkheimer, Lukács und den Positivismus", in Zeitschrift für Soziologie, 14o. ano, caderno 4, agosto, 1985, pp. 315-329. 
produtividade mostrou-se refreada nas três décadas subseqüentes à Guerra - em trabalhos circunstanciais, como diz Alfred Schmidt, e em apontamentos que Horkheimer realizou entre 1950 e 1969, publicados postumamente.

Quem hoje deseja compreender a motivação genuína do materialismo de Horkheimer e avaliá-lo num novo contexto teórico deve se reportar à substância de sua obra, aos trabalhos que apareceram antes do fim da Guerra - quando um autor tem sua obra apreciada, tem o direito de ser tomado a sério no essencial. Eu me permito, porém, tratar antes de algo secundário, formulando uma questão sobre a história da obra: como se explica o disparate da filosofia tardia de Horkheimer, tal como se apresenta em Notizen? Estes apontamentos estão crivados de contradições. A filosofia da história cunhada pela Crítica da Razão Instrumental, o destino do mundo ocidental determinado pelo triunfo de uma forma de vida totalitária - sua idéia de uma vida coletiva racional de indivíduos autônomos e impassíveis [ungekränkter] dão na verdade o tom; mas, ao mesmo tempo, o autor apega-se com obstinação desesperada, às vezes até mesmo com irrefletida ingenuidade ${ }^{3}$, à herança liberal da época do Iluminismo. A Horkheimer ocorrem sempre as palavras: "O retrocesso parece ser a única meta do progresso. Contudo, tal pensamento é perverso enquanto ainda houver algum sofrimento que possa ser remediado pelo progresso" ${ }^{4}$. De um lado, Horkheimer considera impossível a crítica quando ela perde a base histórica. Ela deve pagar pela perda de seu momento pragmático "com a utopia vã" . Por outro lado, ele reconhece um sentido positivo nesta transformação utópica da crítica, nos termos de um retorno de Hegel para Kant. Sob o título "Regressão Utópica", lemos: "Que o ser, que o interesse transcendente ao próprio progresso tenha perdido a possibilidade

3 Cf. a defesa "em favor de uma associação de clarividentes" (Max Horkheimer, Notizen 1950 bis 1969 und Dämmerung. Notizen in Deutschland, editado por Werner Brede, Frankfurt do Meno, 1974, p. 107).

4 Idem, p. 137.

5 Idem, p. 39.

Educ. e Filos., Uberlândia, v. 21, n. 42, p. 273-293, jul./dez. 2007. 
de se realizar na história da sociedade, na qual ele [o indivíduo] vive, [...] é algo que se tornou ao mesmo tempo mais concreto (na medida em que ele toma conhecimento de que toda a humanidade, e não somente uma parte dela, pode pôr-se em ordem) e mais abstrato (na medida em que seu próprio trabalho se vê afastado da meta através de um caminho infinitamente longo e incalculável). O indivíduo é enviado de volta a formulações gerais, tais como as kantianas relativas à meta final da história cosmopolita" ${ }^{\prime}$.

Esta contradição de forma alguma dialética que se revela abertamente, e que Horkheimer muito menos se dispõe a resolver, poderia, à primeira vista, ser interpretada como um indício, na filosofia tardia, de uma tensão insolúvel entre motivações de duas fases distintas; como se o forte impulso dirigido para a práxis dos anos 30 se contrapusesse à visão histórica da Dialética do Esclarecimento. Esta explicação pode não ser inteiramente falsa - o ceticismo materialista permanece uma atitude constante no pensamento do moralista Horkheimer -, mas ela é demasiado simplista. O único conceito coerente de que Horkheimer então dispunha era aquele do materialismo interdisciplinar - mas este programa somente fazia sentido sob dois pressupostos: as imperfeitas e falíveis [fehlbaren] ciências sociais deveriam ser capazes, efetivamente, de carregar o fardo da pesada pretensão teórica na qual se preservariam os desígnios da grande filosofia; e o curso histórico deveria fornecer a garantia de que aquelas proposições críticas, pelas quais o trabalho interdisciplinar logra obter de início seu ponto de vista, reproduzir-se-iam de modo objetivo em conseqüência dos conflitos sociais e, deste modo, difundir-se-iam. Helmut Dubiel mostrou pormenorizadamente como a confiança de Horkheimer nestes dois pressupostos esvaiuse até o começo dos anos $40^{7}$. Desde então, faltou a seu pensamento um liame unificador.

6 Idem, p. 79.

7 Helmut Dubiel, Wissenschaftorganisation und politische Erfahrung, Frankfurt do Meno, 1978. 
Gostaria de acompanhar o desenvolvimento subseqüente em três passos. Inicialmente, quero fornecer a razão pela qual Horkheimer foi levado a se aproximar das teses de Benjamin sobre a história e a procurar uma colaboração mais estreita com Adorno (1); com isto, lançando um olhar de relance para Adorno, gostaria de lembrar que, na Dialética do Esclarecimento, a intenção de ambos os autores não coincide absolutamente (2); por fim, quero retornar à minha questão inicial e tratar daquelas contradições que Horkheimer deixa sem solução na sua fase tardia, e mesmo na Dialética do Esclarecimento; em ambos os casos, debate-se ele com a inevitabilidade do destino de uma razão instrumental exacerbada até a falsa totalidade (3).

1. Em abril de 1941, quando o exército de Hitler avançava aparentemente sem poder ser detido, Horkheimer transferiu-se para a Califórnia. Quão profundo foi este corte biográfico, é algo que se deixa ler já nos dados exteriores. Com o Instituto de Morning Side Heights, com o círculo estreito dos colaboradores do Instituto, com os últimos números da Revista, Horkheimer deixa atrás de si um mundo que tinha organizado e inspirado intelectualmente. Ele achou-se fora da moldura em que tinham validade as raras combinações de seu talento. Naquela época, Horkheimer teve que se apresentar simultânea e distintamente como pessoa, como mentor intelectual, como pensador original, como filósofo e como cientista chefe; do contrário, ele não teria podido, ao longo de anos a fio, vincular a si e a seu programa estes cientistas bastante produtivos, altamente talentosos, mas de temperamentos, origens e orientações os mais diversos.

No ano de 1941 e no inverno de 1941/42, imediatamente antes do começo do trabalho na Dialética do Esclarecimento, Horkheimer redigiu dois ensaios dos quais se depreendem as razões profundas para a despedida do Instituto de Nova York e para uma cooperação exclusiva com Adorno ${ }^{8}$. Juntamente com as "Teses sobre Filosofia

8 Rolf Wiggershaus, num manuscrito ainda inédito sobre a história da Escola de

Educ. e Filos., Uberlândia, v. 21, n. 42, p. 273-293, jul./dez. 2007. 
da História" de Benjamin, que Hannah Arendt resgatou em Paris e levou para Adorno em Nova York, aparecem "Estado Autoritário" e "Razão e Autoconservação", em uma impressão privada dedicada a Benjamin.

O tratado sobre o estado autoritário pertence aos estudos sobre o nacional-socialismo realizados entre 1939 e 1942 e está, manifestamente, sob influência da teoria de Pollock sobre o capitalismo tardio 9 . Nele, Horkheimer desenvolve uma perspectiva de futuro que explica porque os autores da Dialética do Esclarecimento consideram como consumado o fato de a humanidade ter afundado numa nova barbárie. Se, até então, o fascismo tinha sido compreendido, no Instituto, de uma maneira ainda em certa medida ortodoxa, como transição do capitalismo de monopólio para o capitalismo estatal (e, neste caso, como futuro do liberalismo), agora o regime Nacional Socialista aparece como uma forma mista instável que se deteriora e substitui um socialismo estatal de conformação soviética pelo "estadismo integral". Isto vale para "o tipo mais conseqüente de estado autoritário" - o stalinismo como futuro do fascismo. Este estadismo integral renuncia à práxis do ódio racial, põe fim às lutas entre facções, à disputa de poder e ao que resta de um mundo ainda não totalmente administrado. A malha burocrática espalha-se sobre a sociedade, o controle da polícia estatal secreta invade os últimos refúgios. Horkheimer antecipa, no ano de 1941, a visão de Orwells: “A escolha daquele que se confina num campo de concentração tornou-se ainda mais arbitrária. Caso seja preciso aumentar o

Frankfurt, mostra, retrospectivamente, que esse passo aparentemente forçado foi antes acompanhado de outras expectativas. No que segue, baseio-me no meu posfácio para a nova edição da Dialética do Esclarecimento, Frankfurt do Meno, 1986 [O manuscrito a que se refere Habermas foi publicado em 1986, pela Carl Hanser Verlag, sob o título Die Frakfurter Schule; não faz muito tempo, a obra foi contemplada com uma tradução brasileira: A Escola de Frankfurt História, desenvolvimento teórico, significação política, Difel, 2002. N.T.].

9 Horkheimer/Pollock/Neumann/Kirchheimer/Gurland/Marcuse, Recht und Staat im Nationalsozialismus, editado por Helmut Dubiel e Alfons Söllner, Frankfurt do Meno, 1981. 
número de habitantes do campo, caso este número venha a diminuir e não se consiga de forma alguma preencher novamente o lugar deixado pelos exterminados, sim, no fundo, cada um de nós poderia estar no campo de concentração"10.

O local no qual este ensaio foi publicado não é de modo algum acidental; Horkheimer distancia-se da concepção histórica materialista e evolui na linha de Benjamin. Ele agora considera possível que o aumento das forças produtivas possa tanto vir a produzir o socialismo como liquidá-lo. O que uma vez foi chamado de "socialismo" parece ter perdido toda relação interna com o progresso histórico. A esperança revolucionária não possui mais nenhuma ancoragem no mundo, ela é utópica no mau sentido; seja como for, ficou sem lugar. A esperança numa tensão dialética intrínseca ao processo histórico esvaiu-se.

Se agora só pode ocorrer de se saltar para fora do contínuo da história, é porque as tendências históricas observáveis perderam todo interesse mais sério. $O$ que ainda compensa estudar são somente os invariantes responsáveis pela continuidade da desgraça e da opressão. O que demonstra interesse é unicamente a estrutura de uma dominação que tomou conta do progresso na forma da razão instrumental. Não mais Marx indica o caminho, mas Nietzsche. Não é a teoria histórico-social que deve explicar "porque a humanidade, ao invés de adentrar num estado verdadeiramente humano, afunda num novo tipo de barbárie"11, mas uma crítica radical da razão que denuncia o íntimo parentesco entre razão e dominação. Este já era o tema do tratado "Razão e Autoconservação", no qual Horkheimer reveste as velhas idéias de uma nova e característica roupagem.

Em seus trabalhos sobre a filosofia da história e da sociedade burguesa, Horkheimer acompanhava desde há muito o processo

${ }^{10}$ Max Horkheimer, "Autoritärer Staat". In Werner Brede (org.) Gesellshaft im Übergang, Frankfurt do Meno, 1972, p. 21.

${ }^{11}$ Max Horkheimer \&Theodor W. Adorno, Dialektik der Aufklärung, Amsterdam, 1947, p. 5 [tradução brasileira: Dialética do Esclarecimento, Rio de Janeiro, Zahar, 1985, p. 11].

Educ. e Filos., Uberlândia, v. 21, n. 42, p. 273-293, jul./dez. 2007. 
de atrofia pelo qual a razão objetiva revertia-se em subjetiva. Desde sempre interessou a ele como, sob as condições da sociedade burguesa nascente, o conceito de razão foi definido em função das relações de autoconservação individuais e "reduzido a seu significado instrumental"12. Ele estabeleceu uma conexão entre o egoísmo burguês e a instrumentalização da razão em favor do interesse individual isolado [monadische]. Mas esta razão instrumental tinha surgido somente como um produto derivado [Spaltprodukt] da época burguesa; ela deveria se retirar numa formação pós-burguesa da sociedade que resgataria a promessa de uma razão substancial normativa, emergente em lugar da razão instrumental. Ora, esta esperança Horkheimer desde então deixou de acalentar.

Com a ascensão do fascismo e o futuro que se desenha no estadismo integral, a idéia burguesa de razão aparece sob uma outra luz: a sociedade liberal caracteriza o último estágio ainda digno do homem em um, ao que parece, irreversível processo de autodestruição da razão. Poucos anos antes, em "Materialismo e Moral", Horkheimer tinha ainda assinalado que a idéia de uma sociedade digna do homem, na qual algo como uma moral autônoma perderia sua função e sua razão de ser, seria uma decorrência da própria filosofia moral de Kant. Agora, permanece apenas o lamento de que "a categoria do indivíduo, em que, porém, se conectava toda tensão da idéia de autonomia, não resistiu à grande indústria"13. Com o egoísmo do indivíduo burguês, declina também a consciência moral, e as leis morais perdem seu destinatário: "A instância em que se fundava está liquidada. $\mathrm{O}$ moralista deve desaparecer, pois ele não satisfaz seu próprio princípio"14. Horkheimer desenvolveu este pensamento no excurso "Juliette ou Esclarecimento e Moral". Inconfundivelmente, estamos próximos, em contrapartida, da crítica do progresso de Benjamin, que também desmascara no esclarecimento o traço totalitário.

\footnotetext{
${ }^{12}$ Max Horkheimer, Vernunft und Selbserhaltung, Frankfurt do Meno, 1970, p. 11.

${ }^{13}$ Idem, p. 31.

${ }^{14}$ Idem, p. 32.
} 
Quando Adorno veio a colaborar na redação da versão para impressão de "Razão e Autoconservação", foi Horkheimer que, a partir de um impulso próprio resultante de seu desenvolvimento pessoal, dispôs-se a um trabalho em conjunto com Adorno - isso atestam ambos no ensaio dedicado a Benjamin. Adorno tinha desde o princípio incorporado motivos benjaminianos, que, para Horkheimer, só se tornaram virulentos no começo dos anos 40, sob pressão da experiência política.

2. O trabalho em conjunto na Dialética do Esclarecimento ocorreu na fase em que as biografias intelectuais de Adorno e Horkheimer mais estreitamente se abraçaram. Então, as duas linhas da vida se cruzaram interferindo uma na outra. Quando, depois da guerra, Horkheimer e Adorno afirmam reiteradamente que seus pensamentos seriam apenas "um", generalizam eles a especificidade da constelação entre novembro de 1941 (quando Adorno, que aguardava impacientemente para ir ter com Horkheimer, muda-se para Santa Mônica) e maio de 1944 (quando o trabalho foi terminado como manuscrito apresentado em comemoração aos 50 anos de Friedrich Pollock). Desse modo, escamotearam eles diferenças entre suas posições existentes desde o princípio e que somente retrocederam naqueles anos de intenso trabalho conjunto. A razão profunda para esta aproximação temporária deveu-se, então, mais ao desenvolvimento de Horkheimer do que ao de Adorno. Para um deles, a Dialética do Esclarecimento configurou uma ruptura com o programa seguido pela Revista de Pesquisa Social; para o outro, ela se inseriu na continuidade de um pensamento mais tarde designado como dialético-negativo ${ }^{15}$. A política de publicação dos escritos de Adorno durante os anos 50 e 60 poderia ignorar a história de

${ }^{15}$ Cf. a propósito: W. Bonß \& N. Schindler, "Kritische Theorie als interdisziplinärer Materialismus", assim como Martin Jay, "Positive und Negative Totalität. Adornos Alternativenwurf zur interdisziplinären Forschung", ambos em: W. Bonß \& Axel Honeth, Sozialforschung als Kritik, Frankfurt do Meno, 1982, p. 31 e seguintes; 67 e seguintes.

Educ. e Filos., Uberlândia, v. 21, n. 42, p. 273-293, jul./dez. 2007. 
aparecimento dos textos (até mesmo quando estes retrocedem à época de Weimar) e, assim, dispor todos os manuscritos numa linearidade ideal, porque a obra enraizada desabrochou de fato sem ruptura a partir da raiz inicial. Com efeito, encontram-se em sua filosofia tardia os motivos essenciais dos escritos iniciais ${ }^{16}$.

O prefácio para a Dialética do Esclarecimento principia-se com uma declaração de ceticismo científico dos autores. Seus trabalhos, lemos ali, tinham sido até então norteados pelas atividades científicas estabelecidas e tinham até mesmo incorporado tematicamente disciplinas particulares; tinham eles se limitado "à crítica e ao prosseguimento das teorias especializadas" - "os fragmentos que aqui reunimos mostram, contudo, que tivemos de abandonar aquela confiança" ${ }^{\prime 17}$. Na verdade, é somente Horkheimer que, com estas palavras, revoga o programa de sua conferência inaugural como diretor do Instituto de Pesquisa Social assim como o programa desenvolvido pela Revista de Pesquisa Social. Adorno esteve desde sempre distante da confiança na sociologia e nas ciências especializadas. Já na sua preleção inicial (quase simultânea ao discurso inaugural de Horkheimer) como Privatdozent de Frankfurt, Adorno traçou uma clara linha de demarcação entre filosofia e ciência: "A idéia da ciência é pesquisa; a da filosofia, interpretação"18. Se, contudo, a sociologia lograsse porventura se alçar pela fachada do ruinoso edifício da metafísica e dele resgatar pertences algo esquecidos e praticamente perdidos, estes despojos mal se conservariam, pois somente a filosofia seria capaz de reconhecer o verdadeiro valor do tesouro.

Também o fato de a Dialética do Esclarecimento ter permanecido uma coletânea de fragmentos não constituiu intenção original de

16 "Die Aktualität der Philosophie". In Theodor W. Adorno, Gesammelte Schriften, editado por Rolf Tiedemann, vol 1, 1973, pp. 325 e seguintes; "Die Idee der Naturgeschichte“, op. cit., p. 345 e seguintes. O próprio Adorno declara, na Dialética Negativa, que o capítulo "Weltgeist und Naturgeschichte" empregou motivos de conferências iniciais sobre a idéia da história da natureza.

${ }^{17}$ Dialektik der Aufklärung, p. 5 [tradução brasileira: Dialética do Esclarecimento, p. $11]$.

${ }^{18}$ Theodor W. Adorno, Gesammelt Scriften, vol 1, p. 334. 
Horkheimer. Tendo empregado até então uma forma de exposição convencional, ele planejara uma obra sistemática. Contudo, Adorno estava desde muito cedo convencido de que o caráter fragmentário da exposição é o único apropriado ao pensamento filosófico. A filosofia não dispõe de nenhum método e também de nenhuma hermenêutica. Cabe a ela antes decifrar os vestígios impregnados de fantasia de uma realidade desfigurada; cabe a ela responder com presença de espírito "aos sinais fugazes e evanescentes deixados nas figuras enigmáticas do existente"19.

Além do mais, o jovem Adorno tinha tomado dois motivos de Benjamin: de um lado, a totalidade negativa e a história da natureza; de outro, a afinidade entre mito e modernidade. $\mathrm{Na}$ Dialética do Esclarecimento, eles se conectam com a idéia horkheimeriana de uma razão reduzida à função de autoconservação. Contudo, este texto não se apresenta absolutamente como um tecido inconsútil. A autoria de cada um dos capítulos não é a mesma de forma alguma. Gretel Adorno confirmou para mim, na ocasião, a suspeita que toma o leitor meticuloso: o ensaio-título e o capítulo sobre Sade remontam, na sua maior parte, à Horkheimer; os capítulos sobre Ulisses e sobre a indústria cultural remontam, em primeira linha, à Adorno. Não se trata aqui de uma diferença de cunho meramente estilístico.

A diferença profunda deixa-se reconhecer no modo como ambos os autores reagem a cada uma das aporias mencionadas no prefácio. Se o esclarecimento é compreendido como um processo irrefreável de autodestruição da razão, em que ainda se baseia a crítica que se reserva o direito para este diagnóstico? Desde Nietzsche é sempre a mesma coisa: a crítica radical da razão procede de modo auto-referente; ela não pode ser radical e ao mesmo tempo deixar incólume o próprio padrão de avaliação.

Horkheimer perturba-se com esta aporia. No intuito de poder empregar o efeito emancipador do esclarecimento, ele recua diante da conseqüência segundo a qual o próprio ato do conhecimento

\footnotetext{
${ }^{19}$ Idem, ibidem.
}

Educ. e Filos., Uberlândia, v. 21, n. 42, p. 273-293, jul./dez. 2007. 
esclarecedor se vê afetado pelo processo diagnosticado de autodestruição do esclarecimento. Assim, ele prefere acabar enredado em contradições a ter que renunciar à identidade dos Iluministas, a ter que se converter ao nietzschianismo. No prefácio, as antigas convicções são mantidas obstinadamente: "O esclarecimento tem que tomar consciência de si mesmo para que os homens não sejam inteiramente traídos" ${ }^{\prime 20}$.

Significativamente, encontram-se pontos de apoio para este posicionamento tão-somente naquele capítulo que trai ser um manuscrito de Horkheimer. Refiro-me à insistência num poder crescente da teoria, próximo do escatológico ${ }^{21}$; à crença na propensão antiautoritária do esclarecimento ${ }^{22}$; e, finalmente, à promessa formal do esclarecimento de transcender a si mesmo ${ }^{23}$. Manifestamente, afirmações nesse sentido irrompem sem reservas somente no Eclipse da Razão, cuja responsabilidade é exclusiva de Horkheimer. Ali, afinal, Horkheimer não hesita em fazer, para não ter que tomar da própria Dialética do Esclarecimento sua função esclarecedora, uma autocrítica totalizante da razão e seriamente abrangente ${ }^{24}$ : “a razão só pode realizar sua racionalidade por meio

${ }^{20}$ Dialektik der Aufklärung, p. 9 [tradução brasileira: Dialética do Esclarecimento, p. 15].

21 "O espírito de uma tal teoria intransigente seria capaz de inverter a direção do progresso impiedoso, ainda que este estivesse em vias de atingir sua meta" (Dialektik der Aufklärung, p. 57) [tradução brasileira: Dialética do Esclarecimento, p. 52].

22 “[...] que apenas subterraneamente, é verdade, se comunica com aquela utopia inerente ao conceito de razão" (Dialektik der Aufklärung, p. 113) [tradução brasileira: Dialética do Esclarecimento, p. 91].

23 "O próprio esclarecimento tornado violência devido ao seu próprio poder seria capaz de romper os limites do esclarecimento" (Dialektik der Aufklärung, p. 244) [tradução brasileira: Dialética do Esclarecimento, p. 194]; “O fato de Sade não ter deixado a cargo dos adversários a tarefa de levar o esclarecimento a se horrorizar consigo mesmo, faz de sua obra uma alavanca para salvação do esclarecimento" (Idem, p. 141) [tradução brasileira: Dialética do Esclarecimento, p. 111].

24 “A possibilidade de uma autocrítica da razão pressupõe, em primeiro lugar, que o antagonismo entre razão e natureza encontra-se numa fase aguda e 
da reflexão sobre a enfermidade do mundo como produzida e reproduzida pelos homens; com uma tal autocrítica a razão permanecerá ao mesmo tempo fiel a si mesma, posto que permanecera fiel ao princípio da verdade que devemos unicamente à razão, a saber, aquele que não se curva a nenhum interesse particular" 25 .

Totalmente diferente é o que se passa com Adorno. Diante da aporia da crítica da razão auto-referente, guardou ele uma grande serenidade, pois podia recorrer a um outro motivo. Ele não precisava contar unicamente com a força esclarecedora da crítica filosófica; esta bem podia ser deixada gravitando em torno do paradoxo de um pensamento identitário desmentido por si mesmo e, simultaneamente, radiografado a partir de dentro. Para ele, a genuína experiência estética da arte moderna, notadamente, se oferecia como uma fonte independente de conhecimento ${ }^{26}$. Um trabalho, realizado então com a colaboração direta de Horkheimer, envolveu uma elaboração da verdade, da aparência e da reconciliação que, anos mais tarde, tornou-se significativa para a filosofia tardia de Adorno em grande medida: o trabalho sobre Schönberg, redigido em 1940 e publicado em 1948 como primeira parte da Filosofia da Nova Música. ${ }^{27}$ No teor utópico do belo artístico, é a mimese que guarda, muda e carente de significado, aquele potencial irracional de uma razão desfigurada pelo imperativo da

catastrófica e, em segundo lugar, que a idéia de verdade ainda é acessível neste estágio de completa alienação" (Max Horkheimer, Zur Kritik der instrumentellen Vernunft, Frankfurt do Meno, 1967, p. 165) [tradução brasileira: Eclipse da Razão, Rio de Janeiro, Labor, 1976, p. 188].

${ }^{25}$ Idem, ibidem.

${ }^{26}$ Axel Honneth indicou-me que este motivo aparece também em Horkheimer, especialmente na fase da reorientação. Max Horkheimer, "Art und Mass Culture", in Zeitschrift für Sozialforschung, ano 9, 1941, p. 290 e seguintes. Para o pensamento de Horkheimer, este motivo não adquiriu, no entanto, nenhum poder de conformação.

${ }^{27}$ Cf. também Albrecht Wellmer, "Wahrheit, Schein und Versöhnung. Adornos ästetische Rettung der Modernität". In Friedburg, Ludwig von \& Habermas, Jürgen (org.). Adorno-Konferenz 1983, Frankfurt, 1983, p. 138 e seguintes.

Educ. e Filos., Uberlândia, v. 21, n. 42, p. 273-293, jul./dez. 2007. 
autoconservação. Isso cria um conjunto de referência recíproca entre estética, arte e dialética negativa que encerra em si o que a crítica filosófica sozinha não pode mais sustentar: a esperança anarquista de que um dia a totalidade negativa venha a rebentar, como que fulminada por um raio ${ }^{28}$.

3. A diferença nunca resolvida entre Horkheimer e Adorno, apontada na Dialética do Esclarecimento, esclarece em parte a atitude hesitante que distingue tão notavelmente Horkheimer de Adorno depois de seu retorno para a Alemanha - até mesmo no que se refere a sua política de publicação. Enquanto Adorno, depois da guerra, retoma imediatamente - com a Filosofia da Nova Música, Mínima Moralia, Prismas e Dissonâncias - os trabalhos dos anos 30 e 40, mantendo destarte presente a Dialética do Esclarecimento como uma construção de pano de fundo, Horkheimer hesita com a edição alemã de sua Crítica da Razão Instrumental até o ano de 1967. Os ensaios e conferências publicados nos anos 50 e 60 atestam uma produtividade surpreendentemente suspensa que deixa talvez reconhecer um novo tom, mas nenhum novo posicionamento teórico - embora também sem qualquer identificação com a postura de outrora. A hesitação de Horkheimer diz respeito a ambas as fases de sua biografia intelectual: ao trabalho conjunto com Adorno na Califórnia não menos que ao trabalho do Círculo em Nova York.

Horkheimer arrastou até o começo dos anos 60 o plano de tornar novamente acessíveis seus ensaios da Revista de Pesquisa Social. Por fim, rejeitou o plano - o motivo se encontra numa carta de recusa à editora S. Fischer de junho de $1965^{29}$. Em abril de 1968, porém, isto já está muito distante. Um prefácio para nova

${ }^{28}$ Jürgen Habermas, Theorie des kommunikativen Handelns, vol. 1, Frankfurt do Meno, 1981, p. 489 e seguintes. Sobre a posição da Dialética Negativa na obra tardia de Adorno, a interpretação contrária de Michael Theunissen, "Negativität bei Adorno“. In Adorno-Konferenz 1983 , p. 41 e seguintes; Herbert Schnädelbach, "Dialektik der Vernunftkritik", op. cit., p. 66 e seguintes.

${ }^{29}$ Cf. Max Horkheimer, Kritische Theorie, editado por A. Schmidt, vol. II, Frankfurt do Meno, 1968, p.vii. 
publicação reitera o distanciamento que Horkheimer havia assinalado na carta citada: "apresentar para publicação os ensaios teóricos iniciais sem que o autor os relacione com um conhecimento do presente significaria [...] renunciar à pretensão de lhes conceder valor real" ${ }^{\prime 30}$. Uma modificação apropriada da perspectiva histórica encerra a observação seguinte, segundo a qual "desde o fim da guerra" a meta da sociedade justa teria se extraviado. Horkheimer já havia consumado, no começo dos anos 40, a ruptura com a posição sustentada nos ensaios da Revista dos anos 30. Assim, muita coisa permanece incompreensível no prefácio para nova publicação quando não se tem presente que, em 1968, sobrepõem-se dois movimentos contrastantes - também a Dialética do Esclarecimento nisto toma parte; apesar do pedido de Adorno, Horkheimer hesita quanto a uma segunda edição do grande livro até 1968.

Já mencionei a razão profunda para esta hesitação: Horkheimer tem dificuldade em levar a efeito, em vista daquelas aporias assinaladas no prefácio da Dialética do Esclarecimento, uma crítica auto-referente da razão. Ele não podia recorrer, como Adorno, ao teor mimético que se dissimula nas obras esotéricas da arte moderna; e também não desejava, como se dá com os seguidores de Nietzsche, resvalar para o irracionalismo. Na verdade, o "pavor com que se consuma o curso rumo ao mundo racionalizado, automatizado e administrado" ${ }^{31}$ não deixa espaço algum para se duvidar de uma razão instrumental exacerbada até a totalidade. Mas Horkheimer almejava permanecer fiel a seu impulso original, "no mal existente, manter presente o outro", sem abrigar-se na sabedoria divina. Mas como poderia ainda a crítica filosófica fiar-se na relação com o inteiramente outro? Aquela sua carta de 1965 para a editora S. Fischer, com a qual declinara a republicação de seus antigos trabalhos, conclui-se com a impressionante confissão: "minha hesitação origina-se da

\footnotetext{
${ }^{30}$ Idem, p. ix.

${ }^{31}$ Max Horkheimer Kritische Theorie, editado por A. Schmidt, vol. I, Frankfurt do Meno, 1968, p.xi.
}

Educ. e Filos., Uberlândia, v. 21, n. 42, p. 273-293, jul./dez. 2007. 
dificuldade [...] em renunciar à crença na realização da idéia da civilização ocidental num futuro próximo, e, contudo, responder por esta idéia - sem contar com a Providência, sim, contra o progresso por ela prescrito"32. A filosofia tardia de Horkheimer, que se apresentou na forma de apontamentos diários e que Alfred Schmidt caracterizou de modo convincente ${ }^{33}$, gravita em torno desta aporia.

O último Horkheimer não retornou, como podemos constatar, à crença religiosa; mas a religião aparece agora como a única instância que permitiria distinguir (caso bastasse apenas o reconhecimento) o verdadeiro do falso, o moral do imoral - somente ela poderia emprestar à vida um sentido transcendente à pura autoconservação. No seguinte apontamento, que bem podemos ver como uma continuação tardia de sua correspondência com Walter Benjamin de meados dos anos 30, lemos: “O ato aterrador que cometo, o sofrimento que deixo subsistir, subsistem tão-somente no instante em que têm lugar no íntimo da consciência humana que os recorda, e extinguem-se com ela. Não tem sentido algum dizer que depois disso seriam ainda verdadeiros. Não mais são, não são mais verdadeiros: ambas as coisas são uma só. A menos que tenham sido salvaguardados em Deus. Pode-se admitir isto e não obstante levar a sério uma vida sem Deus? Esta é a questão da filosofia" ${ }^{34}$. Mais ou menos isto Benjamin perguntou naquela época, em 1937, e Horkheimer respondeu, com insípida sensatez, que os assassinados são realmente assassinados. Num ensaio desta época, ele explicou-se da seguinte maneira: “Todos estes anseios de eternidade, do advento da justiça e da sobrevinda do bem universal são, em oposição à apatia da atitude positivista, comuns ao pensador materialista e ao religioso. Mas enquanto este último se tranqüiliza com o pensamento de que tais anseios seriam

\footnotetext{
${ }^{32}$ Max Horkheimer Kritische Theorie, vol. II, Frankfurt do Meno, 1968, p.xi

${ }^{33}$ Alfred Schmidt, "Die geistige Physiognomie Max Horkheimers", introdução a Notizen 1950 bis 1969, p.xl.

${ }^{34}$ Max Horkheimer, Notizen 1950 bis 1969, p. 11.

${ }^{35}$ Max Horkheimer Kritische Theorie, vol. I, p. 372.
} 
seguramente realizados ao final, o primeiro se deixa dominar pelo sentimento do abandono infinito dos homens, que é a única resposta verdadeira para a esperança impossível"35. Naquela época, Horkheimer em particular ainda nutria a esperança de que a teoria crítica da sociedade seria capaz de transportar, num meio científico, o conteúdo racional da tradição filosófica. É o mesmo pensamento insistentemente pós-metafísico, crítico da filosofia, que ainda coage Horkheimer a considerar como única alternativa ao positivismo desolador não novamente a filosofia, e também não o teor da dialética negativa, mas sim a teologia. Também agora esta consideração não leva a um resultado afirmativo. Num apontamento seguinte, a propósito da Teoria Crítica, Horkheimer afirma: "Ela substituiu a teologia, mas não encontrou nenhum novo céu que pudesse indicar, nem mesmo um céu terreno. Mas não pode, é certo, abandonar sua idéia, e por isso sempre se interroga sobre o caminho que conduz até ele. Como se não tivesse sido precisamente sua a descoberta de que o céu para o qual se pode indicar o caminho não é nenhum céu" ${ }^{\prime \prime 6}$.

O fato de Horkheimer recorrer à teologia efetivamente, e não apenas hipoteticamente, resulta da ameaça de ruína de seus próprios fundamentos, uma vez que não somente a filosofia da história perdeu sua base histórica, mas também se radicalizou a crítica total da razão - o Horkheimer tardio não quer, é certo, resignar-se a isto, mas não vê nenhuma outra saída. Acha-se em Notizen um pensamento que poderia talvez recuperar para a crítica uma parte de sua autoconfiança: "A linguagem, quer queira quer não, deve manter a pretensão de ser verdadeira" ${ }^{37}$. E mais adiante: "A verdade da fala não corresponde ao juízo puro e independente, tal qual impresso num papel, mas sim à conduta daquele que fala para com o mundo, conduta que se expressa no juízo, concentrase neste ponto, reporta-se a este objeto em particular" 38 . Mas

\footnotetext{
${ }^{36}$ Max Horkheimer, Notizen 1950 bis 1969, p. 61.

${ }^{37}$ Idem, p. 123.

${ }^{38}$ Idem, p. 172.
}

Educ. e Filos., Uberlândia, v. 21, n. 42, p. 273-293, jul./dez. 2007. 
Horkheimer tornou-se um filósofo da história demasiado negativista, um crítico da razão demasiado radical, para ainda poder descobrir na ação comunicativa do dia-a-dia um lampejo de razão. Como para rejeitar este pensamento, afirmou certa vez: "Hoje as falas são insípidas, e quem não deseja nelas prestar atenção não está muito longe da verdade. [...] As palavras estão superadas. E, evidentemente, também o estão os atos, na medida em que alguma vez estiveram relacionados com as palavras" ${ }^{\prime 39}$. A filosofia tardia é marcada por um dilema: a Dialética do Esclarecimento não pode ficar com a última palavra, mas ela impede o caminho de volta ao materialismo dos anos 30 . $O$ fato de não poder ficar com a última palavra não tem apenas motivos de natureza intrínseca; pelo menos dois motivos exteriores colaboraram para tanto.

Depois de seu retorno, Horkheimer reconstruiu o Instituto de Pesquisa Social e pôs em curso uma larga gama de experimentos, engajando-se de modo amplo no revigoramento da pesquisa social empírica no nível das técnicas entrementes desenvolvidas nos Estados Unidos. Esta renovação da conexão entre as atividades científicas instituídas não se coadunava com a convicção proclamada na Dialética do Esclarecimento. Nos seus trabalhos críticos ao positivismo, Adorno defendeu, no essencial, sua antiga posição. Horkheimer furta-se ao problema, porquanto propõe uma ciência social dos grupos marginalizados não apenas de motivação ético-social, mas, se possível, desconectada de uma teoria social: "Deduzir o todo a partir da teoria só pode conduzir ao pior"40.

Um outro problema põe-se no plano da política do dia-a-dia. Depois da guerra, Horkheimer passou a manter uma atitude favorável à forma estatal da democracia ocidental e à forma de vida da civilização ocidental que era, na verdade, bem mais francamente afirmativa que a anunciada pelas cuidadosas formulações do prefácio para reimpressão de 1968: “Medir o chamado mundo livre pelo seu próprio conceito, comportar-se

${ }^{39}$ Idem, p. 26.

${ }^{40}$ Idem, p. 87. 
criticamente frente a ele e, contudo, apoiar-se em suas idéias... é direito e obrigação de todo ser pensante" ${ }^{\prime 11}$. Horkheimer fiava-se intuitivamente num potencial racional da sociedade do capitalismo desenvolvido, sobre o qual desesperou-se teoricamente durante muito tempo. Adorno, por outro lado, manteve, na sua análise do "capitalismo tardio", uma exposição que se encaixava no quadro de uma filosofia da história negativista. Horkheimer não encontrou forças para rever esta posição à luz de sua experiência política transformada; em lugar disso, remontou às imagens contrastantes do capitalismo liberal. Naturalmente, ele via como uma limitação da cultura burguesa o fato de que a consciência, a dignidade e a autonomia dos indivíduos enrijecia-se num isolamento frio e não desabrochava na emancipação de todos. Mas o último Horkheimer tornou-se não somente extremamente convencional na sua crítica à cultura, mas sobretudo conservador. Ele julgava agora que a liberdade e a humanidade seriam essencialmente pós-burguesas: "A liberdade de todo homem é a do burguês capaz de desenvolver suas potencialidades. Os fundadores do socialismo moderno não refletiram [...] sobre o fato de que estas próprias potencialidades pertencem ao modo de produção burguês" ${ }^{\prime 2}$.

Esta postura afirmativa em relação às instituições do mundo ocidental, que, porém, se revolta contra o caráter inexorável de uma totalidade que elimina todo traço de individualidade e de liberdade, é, contudo, ambivalente e tem, por assim dizer, uma dupla nacionalidade [einen doppelten Boden]. O sentimento de vida que se exprime nos aforismos da filosofia tardia explica talvez mais facilmente a impotência de seu autor para uma vez mais reunir, numa imagem especular convincente, a compreensão dilacerada da realidade social fragmentada. O Horkheimer que retorna da emigração, apesar de todo orgulho burguês, não se sente em casa num país no qual a recaída na barbárie continua sendo possível. Esta terra permanece estrangeira e inquietante para ele até o fim

${ }^{41}$ Max Horkheimer, Kritishe Theorie, vol. 1, p. xiii.

${ }^{42}$ Max Horkheimer, Notizen 1950 bis 1969, p. 153. 
de sua vida. No fim de 1960, ele anota para si mesmo: “Em 1960, o passado nacional-socialista foi submetido na Alemanha à 'repressão'. [...] Na realidade, de acordo com a dinâmica psicológica, havia chegado o momento de se rebelar contra o controle de nossa própria conduta imposta por estrangeiros. Entrementes, chegamos a ser tão fortes que nós mesmos podemos nos permitir censurar o passado, dir-se-ia livre e espontaneamente. [...] Com quanta maior razão se procederá então, uma vez isso concluído, contra aqueles que triunfavam em 1945 quando a Alemanha era derrotada, contra os povos ensoberbecidos do ocidente que em sua estupidez abateram os alemães e se aliaram aos russos, contra aqueles que já necessitam dos alemães de modo premente, contra os indivíduos, emigrantes, judeus, elementos duvidosos que desde aqueles anos tornam a assumir cômodas posições sem que tenham ouvido silvar as bombas 'conosco', nem compartilharam conosco angústias e lágrimas. [...] Agora estamos ainda na etapa da culpa coletiva e da amizade com Israel, mas uma hora isso também chegará ao fim. Em breve traçaremos uma linha final" ${ }^{\prime 3}$.

Embora a desavergonhada reação de 8 de maio de $1985^{44}$ pareça confirmar esse receio, não devemos acatar as palavras de Horkheimer como sendo a verdade pura e simples. Certo é, no entanto, que elas exprimem uma verdade com a qual Horkheimer viveu na República alemã e com a qual, solitário, prolongou sua Teoria duplamente fraturada confiando-a às páginas de um diário.

Tradução de Maurício Chiarello, doutor em Filosofia pelo Instituto de Filosofia e Ciências Humanas da UNICAMP.

${ }^{43}$ Idem, p. 146.

${ }^{44}$ Jürgen Habermas, "Entsorgung der Vergangenheit". In Die Neue Unübersichtlichkeit, Frankfurt do Meno, 1985. 
